ARCHEION, T. CXXI

WARSZAWA 2020

ISSN 0066-6041

e-ISSN 2658-1264

DOI 10.4467/26581264ARC.20.012.12969

MAIK SCHMERBAUCH

ORCID $\underline{\text { 0000-0001-9386-389X }}$

schmeichi@web.de

(University of Hildesheim, Germany)

\title{
ESTABLISH A NEW FILE PLAN IN A DIOCESE OF THE GERMAN CATHOLIC CHURCH
}

Key words: German Catholic Church, church records, church administration

\begin{abstract}
In the article, the author presents a diocese-wide records management project in Germany that began in 2010. Also, the results of the processes are discussed, as well as the various steps in implementing a new file plan. The need for a new file plan in the diocese's parishes has a historical context in the history of the German Catholic Church over the last two decades. Because the Catholic Church has the same administrative system from the Vatican to diocese to parish in almost every country in the world, the article's findings can be transferred into the parish records management processes of the dioceses of other countries.
\end{abstract}




\section{MAIK SCHMERBAUCH}

ORCID 0000-0001-9386-389X

schmeichi@web.de

(Uniwersytet w Hildesheim, Republika Federalna Niemiec)

\section{WPROWADZENIE NOWEGO WYKAZU AKT DLA DIECEZJI NIEMIECKIEGO KOŚCIOŁA KATOLICKIEGO}

Słowa kluczowe: niemiecki Kościół katolicki, akta kościelne, administracja kościelna

\section{Streszczenie}

W artykule autor zaprezentował zainicjowany w 2010 r. projekt zarządzania dokumentacją na poziomie diecezji w niemieckim Kościele katolickim. Przedstawione zostały wyniki wdrożenia projektu, a także poszczególne etapy wprowadzania nowego wykazu akt. Potrzeba opracowania nowego wykazu akt została omówiona w kontekście dziejów niemieckiego Kościola katolickiego na przestrzeni ostatnich dwóch dekad. System administracyjny Kościoła katolickiego jest podobny niemal we wszystkich państwach na świecie, poczynając od Watykanu, poprzez diecezje, na pariafiach kończąc. W związku z tym, przedstawione w artykule wyniki badań autora mogą być zastosowane do procesów zarządzania dokumentacją parafialną w diecezjach w innych krajach. 


\section{Situation: the new structures of German catholic dioceses}

Case studies or practical reports with theoretical aspects about the implementation of a file plan in German Catholic parish records have not yet been the focus of research. In fact, there are no articles on this subject. Over the last decade, a few German articles have been published about the modernisation of the German Catholic Church's administration and its internal organisation structures, but these have only lightly touched upon important records management issues ${ }^{1}$. Therefore, this case study is an opportunity to present the outcomes of a church project to implement records management principles. It reveals that records management is an important element of business, even in a religious institution such as the Catholic Church. This case study describes a diocese-wide records management project in Germany that began in 2010, and discusses the results of the processes, as well as the various steps in implementing a new file plan. The need for a new file plan in the diocese's parishes has a historical context in the history of the German Catholic Church over the last two decades. Because the Catholic Church has the same administrative system from the Vatican to diocese to parish in almost every country in the world, this article's findings can be transferred into the parish records management processes of the dioceses of other countries.

Since the late 1990s in Germany, several bishops of the Catholic Church have exercised their canonical power through a regulation in the code of the canon law of the Codex Iuris Canonici (CIC), $\S 515^{2}$, "to erect, suppress, or alter parishes". They have decided to restructure their almost two-centuryold traditional dioceses parish system ${ }^{3}$, because of the general forward-facing

${ }^{1}$ Articles of the last decade: P. Pfister, Novellierung der "Anordnung über die Sicherung und Nutzung der Archive der katholischen Kirche": Einführung, Text und Kommentar (Amendment to the Order on the safeguarding and use of the archives of the Catholic Church: Introduction, Text and Commentary), „Der Archivar, Zeitschrift für Archivwesen“ 2014, Band 67, s. 172-180; W. Steinbrecher, Prozessorientierte Ablage (Process-based records), Wiesbaden 2010; A. Zünd, Visitation und Controlling in der Kirche (Visitation and controlling in the Church), Berlin 2006. Older articles of records management processes e.g.: W. Leesch, Registraturpläne für Pfarregistraturen (File plans for parishes' records management), „Der Archivar. Mitteilungsblatt für deutsches Archivwesen“ 1957, Band 10, s. 195-204. As opposed to the Catholic Church, the Protestant Church in Germany has published many more articles on the development of records management in its administration. But this should be explored in a special report about Protestant parishes in the future.

2 See: Codex Iuris Canonici, The Code of Canon Law, published on behalf of Pope John Paul II, Vatican City 1983, $§ 515:$ “ $§ 1$. A parish is a certain community of the Christian faithful stably constituted in a particular church, whose pastoral care is entrusted to a pastor (parochus) as its proper pastor (pastor) under the authority of the diocesan bishop. §2 It is only for the diocesan bishop to erect, suppress, or alter parishes. He is neither to erect, suppress, nor alter notably parishes, unless he has heard the presbyteral council. $\$ 3$ A legitimately erected parish possesses juridic personality by the law itself".

${ }^{3}$ For the traditional Catholic dioceses system in Germany see: Erwin Gatz, Geschichte des kirchlichen Lebens in den deutschsprachigen Ländern seit dem Ende des 18. Jahrhunderts, 
challenges of ongoing secularism, minor Catholicism, fewer priests, declining faith and the generally decreasing meaning of the Catholic religion to many people. Thus the bishops and their main diocesan administration located at bishops' seats conducted a revolutionary change of the parish system. In this process, often several separate Catholic parishes in adjacent territories had their longtime independent administrative status removed. They were merged into a parish system of one single main administrative parish with further dependent sub-parishes. In a very painful process for the church faithful and believers, and their traditional Catholic life, the bishops even decided in some cases that parish churches needed to be closed altogether, and afterwards, some were sold as secular premises for other businesses. But this sell-off occurred only in parishes with small and decreasing Catholic communities and fewer mass or service visitors. These mergers resulted in fundamental changes to the Catholic life of a community in a village or part of a city, when, from one day to the next, they had to join a neighbouring parish. All in all, the new administrative ecclesiastical system was absolutely necessary from a business management perspective, but caused confusion between the priests and the bishop's diocesan administration ${ }^{4}$.

\section{Need for a modern archives and records management}

If administrations like the dioceses of the Catholic Church change the character of their traditional structure, it has an impact on their organisational

Band 1: Die Bistümer und ihre Pfarreien, Freiburg 1991 (E. Gatz, History of ecclesiastical life in the German-speaking countries since the end of the $18^{\text {th }}$ century, Vol. 1: The Dioceses and their parishes, Freiburg 1991).

${ }^{4}$ For the restructuring process of German dioceses, the following literature is recommended: Parochialer Wandel in Deutschland. Linkliste zu den Strukturveränderungen in den deutschen Bistümern, hrsg. von der Westfälische Wilhelms-Universität Münster Katholisch-Theologische Fakultät Seminar für Pastoraltheologie, Münster 2009 (Parochial change in Germany. List of the structural changes in German dioceses, published by the Catholic Theological Faculty for Pastoral Theology of the Westfalian Wilhelms University Münster, Münster 2009); Das Profil sozialer Einrichtungen in kirchlicher Trägerschaft im Kontext von Kooperationen und Fusionen, Eine Handreichung des Verbandes der Diözesen Deutschlands und der Kommission für caritative Fragen der Deutschen Bischofskonferenz, Arbeitshilfen, Nr. 209, Bonn 2007 (The profile of social institutions in ecclesiastical sponsorship in the context of cooperation and mergers, Handbook of the Association of the Dioceses of Germany and the Commission for Charitable Questions of the German Bishops' Conferences, published by the Secretariat of the German Bishops' Conference, Work Aids No. 209, Bonn 2007); "Mehr als Strukturen ... Entwicklungen und Perspektiven der pastoralen Neuordnung in den Diözesen". Dokumentation des Studientages der Frühjahrs-Vollversammlung 2007 der Deutschen Bischofskonferenz, ibidem, Nr. 213, Bonn 2007. ("More than structures... developments and perspectives of the pastoral reorganisation in the dioceses". Documentation of the Study Day of the Spring 2007 Annual General Meeting of the German Bishops' Conference, ibidem, Work Aids, No. 213, Bonn 2007). 
structure, when new units are created in the process or older units cease to exist. This has a considerable influence on the file plan of the institution, which needs to be supplemented with positions of new records of business positions and workflows, or positions need to be eliminated. In any event, after the new structure has been implemented, a traditional records' file plan generally needs to be reviewed, revised or enhanced by the authorised specialist in administration and records management. Thus, the restructuring process in the parishes was introduced by the administration and general archives and records management of the diocese on the one hand, and by the priests and parish office secretaries on the other. This affected two points: the old parishes' inactive records in repositories on church premises, and the future records management in the new parish system where separate former offices were eliminated and one main office in the central parish was implemented. Along with these two points, the question of electronic records and digitisation processes in the Catholic Church attracted the attention of all stakeholders.

For the older inactive records of the former independent parishes that covered a time period from the $17^{\text {th }}$ century up to the middle of the $20^{\text {th }}$ century, the worldwide Vatican's ecclesiastical Code of the Canon Law of 1983 established formal regulations in Can. $\S 486-491^{5}$. So, Can. 486 states: "§1. All documents which regard the diocese or parishes must be protected with the greatest care. $\S 2$. In every curia, there is to be erected in a safe place a diocesan archive, or record storage area, in which instruments and written documents which pertain to the spiritual and temporal affairs of the diocese are to be safeguarded after being properly filled and diligently secured. $\S 3$. An inventory, or catalog, of the documents which are contained in the archive is to be kept with a brief synopsis of each written document." Thus records management has the same importance from a bishop's diocesan seat down to the parish level. Can. 491 specifically discusses the institutional implementation of records management and archives: " $\$ 1$. A diocesan bishop is to take care that the acts and documents of the archives of cathedral, collegiate, parochial, and other churches in his territory are also diligently preserved and that inventories or catalogs are made in duplicate, one of which is to be preserved in the archive of the church and the other in the diocesan archive. $\$ 2$. A diocesan bishop is also to take care that there is a historical archive in the diocese, and that documents having historical value are diligently protected and systematically ordered in it. \$3. In order to inspect or remove the acts and documents mentioned in $\S \S 1$ and 2, the norms established by the diocesan bishop are to be observed." As the Code of Canon Law is mandatory for the Catholic Church in all countries, generally, every Catholic diocese and parish has to fulfil these directions. But because archives and records management

${ }^{5}$ The English version of the Code of Canon Law of 1983 has been released: The Holy See Archive, www.vatican.va/archive/ENG1104/ INDEX.HTM [retrieved: 1.10.2020]. 
was not the priority when faced with the general and much more important ecclesiastical welfare of the faith, qualified archives and records management was often lacking. This was due to both financial constraints and the absence of professional archival staff in most dioceses and parishes. Therefore, in the last decades, these directions have not been respected effectively.

The Vatican has also released a mandatory announcement for the securing and preservation of ecclesiastical archives from $1997^{6}$, and separate regulations of the Federal Conference of Catholic Archives in Germany ${ }^{7}$. After professional diocesan considerations, and always in agreement with the parish stakeholders, older records with archival value were transferred to the main central archive of the diocese at the bishop's seat as a permanent deposit from the parish. In fact, in the past, only old, inactive records from parishes were transferred at the specific request of the parishes, if they were threatened by fire, water or mould in the provisional parish repositories, or if the central archive placed a focus on parish records with special historical value. In any event, there have been no larger numbers of records transfers from parishes to diocesan central archives. This is also because there is less space for the storage of parish records in the central archive, which has mainly been preserving diocesan administration records. This situation changed when the restructuring process began and the central archives had to acquire new repositories with storage space for parish records. After a transfer from a parish to the central archive, the records appraisal process started with a professional archival description, and preservation procedures, mainly according to archival standards like the traditional German ones of the post-war state archivist Johannes Papritz ${ }^{8}$, or partially with newer standards like the ISAD (G), which has become more familiar in church archives. The result of the archival description workflow was a professional ecclesiastical archive of

${ }^{6}$ Päpstliche Kommission für die Kulturgüter der Kirche, Die pastorale Funktion der kirchlichen Archive, Vatican 1997 (Pontifical Commission for the Church's Cultural Heritage, The Pastoral Function of the Church Archives, Vatican 1997).

${ }^{7}$ Comp. Anordnung über die Sicherung und Nutzung der Archive der katholischen Kirche (Kirchliche Archivordnung - KAO), hrsg. von der Bundeskonferenz der kirchlichen Archive in Deutschland 1988, erneuert 2013 (Order on the safeguarding and use of the archives of the Catholic Church (Ecclesiastical Archives - KAO), ed. By the Federal Conference of Church Archives in Germany 1988, renewed in 2013); Arbeitspapiere der Bundeskonferenz der kirchlichen Archive in Deutschland, Hinweise und Anregungen für die Archive kirchlicher Dienststellen und Einrichtungen in Deutschland 1998 (Working papers of the Federal Conference of Church Archives in Germany, references and suggestions for the archives of church services and institutions in Germany 1998).

${ }^{8}$ J. Papritz, Die archivische Titelaufnahme bei Sachakten, Veröffentlichungen der Archivschule Marburg, Institut für Archivwissenschaft, Band 4, Marburg 1997 (The archival title of case files, published by Johannes Papritz, Publications of the Marburg Archives School, University of Applied Studies for Archival Science, Vol. 4); J. Papritz, Die Kartentitelaufnahme im Archiv, Veröffentlichungen der Archivschule Marburg, Institut für Archivwissenschaft, Band 3, Marburg 1998 (The archival title of cards, Publications of the Marburg Archives School, University of Applied Studies for Archival Science, Vol. 3). 
the parish, with a finding aid that is now accessible by historians and researchers, through a personal visit to the special central diocesan archive.

The experiences with older inactive records have been applied to the central archives of the dioceses, which was sometimes problematic from the point of view of church records managers and archivists. In several cases, records folders with one clear record series contained or referred to several different record series. The condition of the general paper-based records, because of the storage in less than ideal parish premises repositories such as basements, was particularly dramatic, and records and folders had been damaged by overfilling and inaccurate handling by secretaries or priests. Also, many records were found simply as loose paper collections in repositories or basements; in some cases, they were wet and mouldy. With such results, an obvious, but not general, statement about records management in the past in the parishes was possible. Although there were file plans in some dioceses and recommendations by the church administrations in the past decades for records filing ${ }^{9}$ for the parishes, in most cases they were not followed, because often the service and the spiritual welfare for the faith were prioritised over professional records management. Also, there was no monitoring or control by the diocesan administration, because of a low level of awareness of the problem, and shortages of human resources. The diocesan administration visited the parishes at irregular intervals and it trusted the secretaries to work appropriately with the records. The consequences of these misunderstandings led, in several cases, to a loss of information in older damaged and mouldy records, and therefore to a loss of parts of the history of the parishes and their churches.

The newer inactive records of all merged parishes, normally from the last fifty years, were still required in the parish offices as references for the operational administrative tasks of the secretary's office. They have now been transferred from all sub-parishes to the repositories of the new main parish with its central operating office. The merger of parishes was a way of implementing much more effective records management, with a new file plan beginning on the merger date, which would respect the new administrative structure and enhance and improve all record-related actions such as filing, retrieval and preservation. It was a chance to avoid the experiences of the past in many parishes. This situation appeared in most the twenty-seven Catholic German dioceses ${ }^{10}$.

${ }^{9}$ Führer durch die Bistumsarchive der katholischen Kirche in der Bundesrepublik Deutschland und in Westberlin, hrsg. von der Bischöflichen Fachkommission für die kirchlichen Archive in Deutschland, München 1977, p. 14-30. (Guide to the church archives of the Catholic Church in the Federal Republic of Germany and in West Berlin, published by the Episcopal Commission for the Church Archives in Germany).

${ }^{10}$ Sekretariat der Deutschen Bischofskonferenz; Bevölkerung, Fläche und Katholiken nach (Erz-) Diözesen, Die Kirchenprovinzen zum 31.12.2010, Bonn 2011 (Secretariat of the German Bishops' Conference; Population, area and Catholics according to (Arch-)Dioceses, The Church Provinces as of 31.12.2010). 
So it was in an ancient German diocese, which controls a large territory in the middle of Germany with over a half million of the faithful. Its administration decided, after long consultation on the restructuring of the diocese after 2010, to decrease its parishes from 300 to 100 new main parishes in the medium term. Between 2010-2012, the diocese established better records management. The plan was to implement a new file plan according to the upcoming parish system in every new main parish office. For this short-term project, the author was hired as an archive and records management specialist, through a professional selection process, with the aim of conducting "Records Management in the diocese's parishes". It was financed by the diocesan administration without any costs or effort for the parishes' finances. The requirements and skills for the post were professional experience and training in archives and records management, a suitable Catholic attitude and a driver's licence for visits to the parishes. The supervision of the temporary records management project was located at the central archives at the bishop's seat.

\section{A new File Plan}

For the implementation of the new file plan, as in other German dioceses, the draft of the ancient German diocese of Cologne was used. This File Plan of Cologne was based on an old file plan of the parishes from the middle of the eighties, as a work plan under the leadership of the Historical Archive ${ }^{11}$. The need for a new file plan was clearly justified by the diocesan administration: "With the establishment of so-called central parish offices in the parishes of the new type, people are offered a reliable starting-point, which competently takes care of pastoral and administrative concerns. The now-existing and binding file plan is intended to free this work from unnecessary ballast on site and to facilitate concentration on the essentials. Its pre-defined structure allows a clear and uniform file management from the outset. The training of new employees or the change of jobs is made easier because all of them have recourse to the same work instrument. Parish peculiarities can be inserted into the file plan, but they do not alter its basic structure. The existing, not very widespread, file plan was obsolete in its conceptual structure and its structure and led to the use of individual solutions. The amalgamation of parishes requires, in any case, a new creation of the files, and thus represents the appropriate time to introduce a new file plan. The work file for parish records in the Archbishopric of Cologne, which has been successfully deployed there for some time, served as a basis for the present file plan" ${ }^{\prime 2}$.

${ }^{11}$ Rahmenaktenplan für Pfarrregistraturen im Erzbistum Köln, Köln 2009 (File Plan for records management in the parishes in the Archdiocese of Cologne).

12 Rahmenaktenplan für Pfarrregistraturen im Bistum Limburg, Limburg 2014, s. 5 (File Plan for records management in the parishes in the Diocese of Limburg). 
The standard "File Plan for the parishes of the diocese" was the result; a new records management tool for preparing implementation in the parishes. The file plan reflected the new parish business workflow and the diversity of Catholic life and faith in the parish. It had a numeric type, with ten main standard positions from 0 to 9 for the record series classification of the parish business workflow:

\begin{tabular}{|c|l|l|}
\hline $\begin{array}{c}\text { File plan } \\
\text { number }\end{array}$ & \multicolumn{1}{|c|}{ Record Series } & \multicolumn{1}{c|}{ Records relating to (examples): } \\
\hline 0 & Parish Administration & $\begin{array}{l}\text { General correspondence with stakeholders, } \\
\text { Annual Plans, organisation of parish events }\end{array}$ \\
\hline 1 & Human Resources & Staff (priest and permanent staff, volunteers) \\
\hline 2 & Service & Service and mass schedules, intentions \\
\hline 3 & Proclamation & Canon law issues \\
\hline 4 & Welfare & Health pastoral care, Youth care \\
\hline 5 & Clubs and Associations & Singing groups, Prayer groups, Senior groups \\
\hline 6 & Caritas & Kindergartens, Rest homes \\
\hline 7 & Premises & $\begin{array}{l}\text { Church buildings, inventory, building plans, } \\
\text { cemeteries }\end{array}$ \\
\hline 8 & Properties & Foundations \\
\hline 9 & Finances & Invoices, Budgeting, Donations \\
\hline
\end{tabular}

Under each of these ten main record series, a decimal system for sub-subject positions in the form of -02 and 021 was provided, with the possibility for the secretary to add new positions under the main standard position in the file plan if necessary. Attached to the file plan was a retention schedule for the main records series over the office life cycle. Additionally, the new file plan was formed in a user friendly electronic windows folder structure for the management and storage of the rising number of electronic records.

\section{Preparing the implementation}

After the new file plan was developed, it was necessary for the project manager, as a first step, to inform all of the parishes of the diocese in advance about the new initiative. As general preparation for the implementation, in several meetings and conferences, the secretaries of a special territorial district of the diocese were invited to the bishop's central seat, on the approval of the parish priests, for a presentation and some introductory theory on the new records 
management tool. To achieve better filing and more effective paper preservation of active and inactive records, the physical folders were enhanced to avoid the poor records conditions that had appeared in several previous records transfers. New adhesive labels were stuck on the backs of the folders with the accurate file plan number, the time period of the records, and a short description of the records in the folder. These new folders were slightly oversized, in contrast to the long-used traditional German Leitz folders, and they provided a more stable four-hole flap, instead of the normal two-hole flap, so as to protect the records more effectively.

The next assignment after the theory lessons was planning the practical implementation of the new file plan in all diocese parishes. The diocesan administration announced the aim of implementing modern records management with the bishop's statement in the diocesan-wide official journal ${ }^{13}$. The main goal of the records management project was to implement the new file plan in almost all of the new main parishes, which was approximately 100 parishes for the entire diocese. After the first implementation period in the parishes in 2011, it became obvious that it would hardly be possible to achieve this aim within the project's allotted two years because of normal business-related reasons. Some appointments of the records manager, organised in advance with the parishes in their premises and offices had been cancelled or rescheduled because of annual or sick leave of the stakeholders, a carpool failure, the delayed delivery of new folders, and several other similar factors which were not primarily based on the projects at hand.

Thus, over the entire foreseen project period of 2010 to 2012, the new file plan was officially introduced and implemented in over 60 parishes, more than half of the total. In retrospect, the time period for a complete implementation in all parishes of the diocese should have been about four to five years. But the factual implementation of the file plan in the majority of all diocese parishes allows for an effective evaluation of the experiences in this special records management project, and the impact on the workflow and the outcome.

\section{The project workflow}

The records manager developed a professional plan for the implementation progress and process with the workflow: Step 1) Selection of the parishes in a particular territory, which were recently merged or were soon to be merged; Step 2) Organise a personal appointment in the parish with the responsible secretary and additionally with the local priest as the parish supervisor; Step

${ }^{13}$ Leitlinien zur kirchlichen elektronischen Schriftgutverwaltung, Amtsblatt des Erzbistums Köln, Stück 9, 1. August 2011, s. 214-219. (Guidelines on ecclesiastical records management, published by the Episcopal Vicariate). 
3) The official visit to the selected parish; Step 4) Provide training for the secretary in handling the new file plan, both in theory and with regard to practical records exercises; Step 5) Handover of the new folders; Step 6) Document the results of the visit in an official protocol; and Step 7) Monitor the success of the implementation for maintainability. The central focus of the project was the implementation of the main workflow in part 4) by the records manager. Also, the records manager decided to incorporate several points that were easily understandable from the common standards of the Records Management ISO 15489-1 into the secretaries' records training, improving their further records awareness regarding quality and protection.

The practical implementation process was to first get in touch with the parish office (male or female) secretary and mostly, if he was not prevented from this due to more important welfare tasks, the priest of the parish. In almost all cases, this first contact was friendly and positive. Only in a few exceptional cases were there initially some major prejudices on the part of secretaries against the new file plan and the new folders, based on their unfounded fear of possible changes in their traditional workflow, along with an equally baseless fear of possible unemployment in the future. The next step for the records manager was again to diplomatically explain the project aim to the secretary and priest with an introduction to the new file plan, although they already had some basic knowledge from the communications from the diocesan administration and the pre-meetings. Along with this introduction, the active records collection in the office and the inactive older records and metrics in the parish repositories were examined, so as to gain an impression of the general records management situation and environment in the parish. For further and deeper information, the records manager also created a special questionnaire for the secretary, with records-related questions such as inquiring about the general problems in the management of the parish-related records. This included the implementation of the traditional filing system, the mass of inactive records, the metrics, and the current experience with electronic records management. The new file plan was explained bit by bit, and many practical exercises of filing and retrieval per record series, with training on the numerical positions, were conducted.

Afterwards, it was necessary to clarify when the new file plan had to become active. According to the date of the merger and the existence of the new main parish with its sub-parishes, the new file plan had to start on the date of the merger and all other records before this date needed to be closed completely. With the date of the merger, the new administrative system became active and further records only referred to the new parish provenance. The main parish was then the only administrative representative and records holder. If the merger was completed before the visit of the records manager could take place, the current records needed to be refiled backwards to the merger date. If the merger was planned for the future, the secretary could prepare the new file plan according to 
the merger date. The records of the sub-parishes had to be further filed only in file plan no. zero. Shortly after this intensive introduction, about 30 parishes declared that they understood the system of the new file plan and would be capable of implementing it successfully with further self-training on their own. Another 25 secretaries were initially cautious, but finally accepted the explanations and asked for more time to train and practise. In five parishes, the secretaries doubted that the new file plan would improve records management and needed to be convinced by means of practical exercises that revealed the advantages of the new file plan, such as a faster retrieval process, diocese-wide records consistency and better records preservation. Over half of the parishes reported problems with the new oversized folders, regarding them as too complex and therefore harder to manually handle. The majority wanted to keep the traditional Leitz folders, which only needed to be relabeled on the back.

As a further enhancement, the new file plan was structured in a digital folder system for the electronic records management on a basic computer platform and delivered on a CD. Almost all secretaries, because of the increasing number of electronic records over the last decade, welcomed this electronic platform and conceded that they had been looking for quite some time for a good file structure for their electronic records, often without a satisfactory solution. The records manager also provided practical solutions for good nomenclature of the electronic records and demonstrated how they could be retrieved more efficiently. This process was accompanied by professional information on how to store and preserve the digital documents and with other useful recommendations, such as how to maintain the parish website as an important digital record, using the method of data harvesting. Through questions related to the permanent preservation of the electronic records, it was agreed to establish permanent technical support, by the diocesan administration if necessary. The visits to the parishes had the additional effect for the records manager that the private and professional consultations with the priests and secretaries often revealed distinct, unique non-record-related situations of the parish community, their personal beliefs about the mergers and their general attitude to the dependent sub-parishes. This intensified the attitudes on the current situation of the German Catholic Church, religion and faith in all parts and districts on the entire diocese.

\section{Maintainability}

For the records manager, monitoring the success of the implementation was the last step for the sustainability of the project, and after a certain period, he started an electronic survey via e-mail to the parishes about their experiences with the new file plan. About ninety percent of the parishes confirmed that they were still learning about the new system by practising the daily workflow with all business-related active records. Besides difficulties at the beginning in 
classifying the records consistently in accordance with the new file plan, after a certain period, they became more and more familiar with the new records' positions and the structure of the file plan, and learned to work efficiently with it. Otherwise, about ten percent of the parishes asked for personal training in the parish office. Half of all parishes finally decided to avoid the new stable but oversized folders and sent them back to the diocesan administration. The focus by the records manager on the advantages of the folders for records protection could not ultimately convince these secretaries to replace their beloved and respected traditional German Leitz records folders. The offer of the records manager during the visit that the secretaries could ask questions any time after the implementation of the file plan was taken up frequently via phone and email.

The professional conclusion of the two-year project in a final report was clear. The file plan enhanced the traditional records management remarkably well in a lot of the parishes, and over time, most of the secretaries learned how to use the new paper-based and electronic file plans. The new file plan is an enhancement not only for the older historic records. For upcoming inactive records transfers from parishes to the central archive in the next few decades, the records will have a much better archival description and the appraisal condition will be recorded. However, due to a lack of financial resources as is often the case in church-tax-funded institutions such as the administrations of the Catholic Church, the project was not extended after the initial two years. Therefore, the rest of the parishes which were not officially visited in the project period for file plan implementation still need to be trained by the secretaries who are already familiar with the new plan.

\section{Lessons learned}

The entire project workflow was only developed through the principle of learning by doing and implementing theory in this manner. Therefore the article initially discussed the project's historical background. It further revealed deeper details of the planning process and the challenges, while the implementation was ultimately an important professional experience for similar projects. In the two-year project, almost 60 parishes officially implemented the new file plan. There were several lessons learned while conducting the project. One important experience of which the project manager was not aware at the beginning, was the effort and motivation needed to induce some secretaries to work with the new file plan, by showing them the advantages very clearly. Also, it was observed that not every secretary, after the implementation and training, was on the way to becoming a records professional with the new filing system, so this required time and further guidance. If the project has positively changed the general attitude of parish secretaries to archive and records management, this will be 
a big advantage for the future, so that change management is an important part of the project.

Another point is that a professional needs to personally visit the circumstances of the archive and records management at locations such as the parish premises (e.g. basements), to become aware of the impact of a non-professional handling of records in the past, which can cause a massive loss of information (e.g. mouldy records). Therefore, a theoretical implementation of a new file plan without a records inspection or trust in the locations' stakeholders, will surely yield poorer results. The project manager's lessons learned in the two years were clear: one needs a customised workflow, one must deal diplomatically with the stakeholders, and one really needs time for such territory-wide projects. Yet, taking all professional and personal experiences and concerns together, it will surely be possible to start a similar project in other dioceses of the Catholic Church in Germany and in other countries with a Catholic Church system, because this project revealed that records management is absolutely necessary for all Catholic parishes. Therefore, similar project experiences would further promote the much needed knowledge on ecclesiastical records management.

\section{Bibliography}

Anordnung über die Sicherung und Nutzung der Archive der katholischen Kirche (Kirchliche Archivordnung - KAO), hrsg. von der Bundeskonferenz der kirchlichen Archive in Deutschland 1988, http://www.katholische-archive.de/Portals/0/Medien/PDF/KAO/KAO_2014.pdf [dostęp: 1.12.2020].

Arbeitspapiere der Bundeskonferenz der kirchlichen Archive in Deutschland, Hinweise und Anregungen für die Archive kirchlicher Dienststellen und Einrichtungen in Deutschland 1998, http://www.katholische-archive.de/Portals/0/Medien/PDF/Arbeitspapiere\%20der\%20BuKo. pdf [dostęp: 1.12.2020].

Codex Iuris Canonicii, The Code of the Canon Law, published on behalf of Pope Johan Paul II, Vatican City 1983.

Das Profil sozialer Einrichtungen in kirchlicher Trägerschaft im Kontext von Kooperationen und Fusionen. Eine Handreichung des Verbandes der Diözesen Deutschlands und der Kommission für caritative Fragen der Deutschen Bischofskonferenz, Arbeitshilfen, Nr 209, Bonn 2007.

Führer durch die Bistumsarchive der katholischen Kirche in der Bundesrepublik Deutschland und in Westberlin, hrsg. von der Bischöflichen Fachkommission für die kirchlichen Archive in Deutschland, München 1977.

Gatz E., Geschichte des kirchlichen Lebens in den deutschsprachigen Ländern seit dem Ende des 18. Jahrhunderts, Band 1, Die Bistümer und ihre Pfarreien, Freiburg 1991.

Leesch W., Registraturpläne für Pfarregistraturen, "Der Archivar. Mitteilungsblatt für deutsches Archivwese" 1957, Band 10, s. 195-204.

Leitlinien zur kirchlichen elektronischen Schriftgutverwaltung, Amtsblatt des Erzbistums Köln, Stück 9, 1. August 2011, s. 214-219. 
"Mehr als Strukturen... Entwicklungen und Perspektiven der pastoralen Neuordnung in den Diözesen”. Dokumentation des Studientages der Frühjahrs-Vollversammlung 2007 der Deutschen Bischofskonferenz, Arbeitshilfen, Nr 213, Bonn 2007.

Papritz J., Die archivische Titelaufnahme bei Sachakten, Veröffentlichungen der Archivschule Marburg, Institut für Archivwissenschaft, Band 4, Marburg 1997.

Papritz J., Die Kartentitelaufnahme im Archiv, Veröffentlichungen der Archivschule Marburg, Institut für Archivwissenschaft, Band 3, Marburg 1998.

Päpstliche Kommission für die Kulturgüter der Kirche, Die pastorale Funktion der kirchlichen Archive, Vatican 1997.

Parochialer Wandel in Deutschland. Linkliste zu den Strukturveränderungen in den deutschen Bistümern, hrsg. von der Westfälische Wilhelms-Universität Münster Katholisch-Theologische Fakultät Seminar für Pastoraltheologie, Münster 2009.

Pfister P., Novellierung der "Anordnung über die Sicherung und Nutzung der Archive der katholischen Kirche": Einführung, Text und Kommentar, "Der Archivar. Zeitschrift für Archivwesen" 2014, Band 67, s. 172-180.

Rahmenaktenplan für Pfarrregistraturen im Bistum Limburg, Limburg 2014.

Rahmenaktenplan für Pfarrregistraturen im Erzbistum Köln, Köln 2009.

Sekretariat der Deutschen Bischofskonferenz; Bevölkerung, Fläche und Katholiken nach (Erz-)

Diözesen, Die Kirchenprovinzen zum 31.12.2010, Bonn 2011.

Steinbrecher W., Prozessorientierte Ablage, Wiesbaden 2010.

Zünd A., Visitation und Controlling in der Kirche, Berlin 2006. 